\title{
Pre-service teachers' perceptions of practicum through reciprocal peer mentoring and traditional mentoring*
}

\author{
Seyit Ahmet Çapan ${ }^{\mathrm{a}+}$, Hasan Bedir ${ }^{\mathrm{b}}$ \\ ${ }^{a}$ Harran University, Education Faculty, Şanliurfa, 63190, Turkey \\ ${ }^{b}$ Cukurova University, Education Faculty, Adana, 01330, Turkey
}

\section{APA Citation:}

Çapan, S.A., \& Bedir, H. (2019). Pre-service teachers' perceptions of practicum through reciprocal peer mentoring and traditional mentoring

. Journal of Language and Linguistic Studies, 15(3), 953-971.

Submission Date:13/05/2019

Acceptance Date:03/07/2019

\begin{abstract}
Practicum in pre-service teacher education offers ample opportunities for developing a practical conception of teaching and learning. Yet it may also promote further worry for pre-service teachers if not sufficiently resourced and carefully structured. The present study intended to delve into pre-service teachers' perceptions of practicum undertaken through reciprocal peer mentoring and traditional mentoring trajectories. Designed as a quasiexperimental study, this longitudinal study collected mainly qualitative data through reflective journals, individual interviews and audio-records of peer conferences. The present study revealed a dire need for restructuring the traditional mentoring model currently used in pre-service teacher education programs. The study also unraveled that integration of reciprocal peer mentoring with systematic opportunities for peer conference and peer observation might be a viable suggestion to resolve the perceived shortcomings in practicum. Moreover, the study proposed that apart from an earlier onset of teaching practices, periodic rotations in teaching practices and mentormentee pairings might help to maximize contributions of engagement in practicum experiences.
\end{abstract}

(C) 2019 JLLS and the Authors - Published by JLLS.

Keywords: Practicum; mentoring; traditional; peer; reciprocal

\section{Introduction}

Reciprocal peer mentoring (RPM) refers to the activities of a pair of teachers undertaken in the workplace in order for continuous progression towards improvement (Zwart, Wubbels, Bergen \& Bolhuis, 2009). Contrary to the hierarchical relationship governing traditional mentoring practices, RPM engages two peers of equal or nearly equal status in an inherently mutual relationship so that both peers have something to contribute to one another's personal and professional development (Nguyen, 2013). RPM typically comprises a cyclical process of planning, observing and data collection, and providing feedback and reflective analysis (Joyce \& Showers, 1980). In the planning stage, peers meet before teaching in order to share plans and set a goal for teaching. In the second stage, one of the peers observes and collects data about the performance of the other peer who is actively teaching in the classroom. In

\footnotetext{
* This manuscript is derived from the first author's doctoral study titled "Reciprocal Peer Mentoring in Pre-Service ELT Practicum in terms of Teaching Concerns and Teacher Efficacy Beliefs."

${ }^{\dagger}$ Corresponding author. Tel.: +09-414-318-3466

E-mail address: sacapan@harran.edu.tr
} 
the last stage, the peers meet following the teaching practices to make a reflective analysis of their performance and exchange feedback to improve one another's effectiveness.

Practicum in pre-service teacher education (PTE), however, provides invaluable sources of handson teaching experiences and a realistic understanding of the dynamics of teaching in actual classrooms. Despite its overwhelmingly strong potential to contribute to pre-service teachers' development, practicum perplexingly features as the least intentional component of PTE (Levine, 2002). Several researchers (Darling-Hammond, 2006; Zeichner, 2010) contend that practicum experiences are vulnerable to serious flaws, since they are rather haphazard and insufficiently resourced. One of the leading problems in the practicum process concerns mentoring practices. Apparently, mentoring practices in practicum are deficient in many aspects due to various factors such as the hierarchical nature of mentoring relationships, little feedback from mentors, time restrictions and heavy workload of mentors, lack of training on effective mentoring, and lack of commitment for the mentoring role (Beck \& Kosnick, 2000). The notorious twice-a-year model of supervisory observations features as another pitfall hindering the espoused contributions practicum is likely to make to pre-service teachers' development (Vidmar, 2006). Similarly, teaching practices per se surface as the other problematic aspect hindering efficiency of the practicum experiences. More specifically, McDonald and Elias (1983) state that initial teaching experiences are "perilous and fraught with risks" (p.1).

\subsection{Literature review}

Certain components including direct observation and reflection are essential in all mentoring models. Nevertheless, previous research (Parker, Douglas \& Kram, 2008; Showers \& Joyce, 1996) has documented specific factors to take into consideration while designing a peer mentoring program. First and foremost, commitment to peer mentoring protocols on the part of both peers is as a key factor contributing to the success of peer mentoring programs (Showers \& Joyce, 1996). As RPM focuses on collegial efforts enhancing professional development, adoption of a non-judgmental and non-evaluative approach also plays a crucial role in establishing effective peer mentoring programs (Vidmar, 2006). Likewise, peer compatibility and selection are vital for success in peer mentoring programs (Walsh, Emslie \& Tayler, 2002). The other key factor in peer mentoring is the notion of reciprocity, which requires a continuous alternation between the roles of mentor and mentee so as to enhance a bidirectional flow of information from and to both peers (Paris, 2010).

Considering that RPM necessarily engages pre-service teachers in various activities including observation, critical reflection and constant exchange of ideas, it allows pre-service teachers to search for and try out new methods in order for solving instructional problems and improving their overall effectiveness as a teacher. Several studies (Britton \& Anderson, 2010; Le Cornu, 2005) documented that RPM formed a sound source of support for pre-service teachers and reinforced collaboration throughout practicum. Working with four pre-service teachers throughout their classroom practices, Britton and Anderson (2010) unveiled that pre-service teachers felt satisfied with peer mentoring because it provided collegial support and practical feedback through regular observations and communication with peers. In addition, the pre-service teachers in Hooker's (2014) study underlined that collaboration with a peer who they could candidly ask about their frustrations and share problems was a major source of support against the challenges in their field-based initial teacher education program. Consistent with Hargraves' (2001) suggestion of collaborative working and learning as a prerequisite skill for effective teachers of future classrooms, RPM surfaces as a viable method to challenge the archaic conception of teaching as an isolated job through cultivating more collaborative dispositions in pre-service teachers. 


\subsection{Research questions}

Taking into account the aforementioned problems regarding overall practicum in PTE, the present study aims to bring a fresh perspective on practicum experiences by assigning some role for pre-service teachers to take agency for their own development and provide mutual mentoring to one another during practicum experiences. What this study specifically intends is to reveal pre-service teachers' perceptions about involvement in the RPM protocols as an alternative to the traditional mentoring (TM) practices. To this end, the present study involves the participants in the RPM apart from TM practices and investigates perceived impact(s) of each set of practices on pre-service teachers' development throughout practicum. To this end, the present study sheds light on the following research question:

- What are the perceptions of the reciprocal peer mentoring group as compared to those of the traditional mentoring group on overall practicum process?

\section{Method}

\subsection{Participants}

The present study comprised a total 20 pre-service ELT teachers assigned to the study and comparison groups with 10 participants in each. The present study used convenience sampling (Creswell, 2012) in order to select the participants. Despite the perceived disadvantages of convenience sampling (Creswell, 2012), two factors made convenience sampling a requirement for successfully carrying out the present study. Firstly, the fact that the practicum schools had to share similar contextual features (socio-economic, physical etc.) for conducting reliable comparisons between the RPM and TM groups urged selecting participants from a restricted geographical area. Secondly, the participants in the RPM group had to be granted certain autonomy to select their peers due to the very nature of extended collaboration they would be involved in throughout practicum.

Upon receiving approval of the administrative board of Çukurova University ELT department for conducting the study, the researcher informed pre-service teachers who were assigned to the practicum schools about the purposes and procedures in this study. Those who volunteered to participate received further information about the responsibilities and tasks they would undertake by accepting to participate in the present study. As criteria for selecting the participants from among those who had volunteered to participate, the present study ensured that all the participants (12 females and 8 males) had completed the compulsory methodology courses before the practicum placement and had no previous teaching experience. Furthermore, the participants were all in the final year of the PTE program and enrolled in the 'School Experience' and 'Practice Teaching' courses in the fall and spring semesters, respectively. To prevent confusion, the present study assigned each participant a number from 1 to 20 (i.e. P1, P2 etc.) and used RPM and TM to distinguish between the participants in the study and comparison groups. Hence, a pseudonym like RPM-P1, which the present study uses in the following chapter to identify the excerpts deriving from participant reflections, stands for the participant numbered 1 in the RPM group while TM-P5 represents the participant numbered 5 in the TM group.

\subsection{Research Design and Instruments}

The present study was a qualitative study. The study was designed as a quasi-experimental study, in which two groups of participants determined as study and comparison groups were compared. In such studies, the study group receives a particular treatment while the comparison group follows the routine procedure. In the present study, the RPM group determined as the study group participated in an intensive training about RPM and undertook the practicum according to RPM whereas the TM group 
(i.e. the comparison group) merely followed the TM practices. As Cresswell (2012) notes, one of the basic features that distinguishes quasi-experiments from a true experiment is the ignorance of random assignment of the participants to study and comparison groups. Since RPM by nature required giving the participants the opportunity to select their partners, it was a must to ignore random assignment in the present study. The researcher made between-groups comparisons in order to report the RPM and TM groups' specific perceptions about practicum. Given the aims of the study, mentoring (reciprocal peer/ traditional) was the independent variable while perceptions of practicum surfaced as the dependent variables.

To examine the perceptions of the participants about practicum, the present study utilized qualitative data. Data collection in this longitudinal study lasted for a full academic year. Data collection tools included reflective journals, individual interviews and audio-records of peer conferences. Regarding reflective journals, the present study required the participants to write weekly journals about their experiences in practicum. Given the challenges of keeping a reflective journal, particularly for inexperienced teachers who are unfamiliar with the concept of reflection and features of an effective journal (Richards \& Ho, 1998), the researcher in the present study developed a template for reflective journals based on a review of previous studies (Vidmar, 2006; Wynn \& Kromrey, 2000; Zwart, Wubbels, Bulhois \& Bergen, 2008) so as to promote the participants' critical reflection on the practicum experiences. One should keep in mind that rather than imposing external foci, the researcher provided the template as a mere framework for encouraging the participants to critically reflect on what worked well/poorly in practicum, notice differences between their initial plans and actual practices, and make inferences for their own development.

Furthermore, the individual interviews served as a means to engage the participants in in-depth thinking about a broad range of issues such as their likes/dislikes about practicum, perceived contributions of the mentoring experiences (RPM or TM) to their professional development, the quantity and quality of support they received and struggles/positive experiences they had throughout practicum. The interviews lasting about 50-70 minutes each were conducted with all the participants at the end of the practicum process. All the interviews were semi-structured. To determine possible interview questions, the researcher prepared a preliminary list of questions deriving from the literature review and consulted to an experienced teacher educator in order to refine the list and identify questions more likely to encourage the participants to freely share their opinions. The researcher audio-recorded and transcribed verbatim all the interviews for further analysis.

In addition, the present study required the participants in the RPM group to audio-record the peer conferences they necessarily had prior to and following each teaching practice. Then, the participants submitted these audio-records via e-mail no later than the day after they visited the practicum school. The audio records performed two critical functions. On the one hand, they ensured that the participants in the RPM group regularly held the conferences. On the other hand, they provided insights into the participants' perceptions about having the practicum experiences through the RPM trajectory. The researcher transcribed verbatim all the audio records of peer conferences for content analysis.

\subsection{Data collection procedures}

Following the introductory visits to the practicum schools, the participants in the TM group started the practicum with the routines in the TM model, which ideally required observing the cooperating teachers in the fall semester, practice-teaching in the spring semester and holding regular briefing and debriefing conferences with the cooperating teachers throughout the practicum. Different from the TM group, the participants in the RPM group observed the cooperating teachers only for four weeks. At the same time, they participated in a training program on RPM, which will be discussed below. Then, the 
RPM group proceeded with the practices in the RPM model, which required regular peer observations and peer conferences apart from the routines in the TM model. During the week following the last teaching practices in the second semester, the researcher held individual interviews with the participants.

The intensive training program on RPM covered the first four-week period when the RPM group observed the cooperating teachers. Given the purposes and design of the study, only the study group participated in the training program. The training intended to help the RPM group gain awareness about their roles and responsibilities in the RPM protocols. The researcher determined the content of the training program as a result of an extended literature review of previous studies (Goh \& Matthews, 2011; Hooker, 2014; Kuru-Gönen, 2012). The content of the training program mainly addressed 7 topics including

$>$ Introduction and discussion of TM

$>$ Introduction to RPM

$>$ Justification for RPM

$>$ Stages and procedures in RPM

$>$ Tips for giving and receiving effective feedback

$>$ Interpersonal communication skills

$>$ Critical reflection

\subsection{Data analysis}

To analyze the data, the present study used content analysis. For the analysis, the researcher created a panel of two separate coders. Both coders, one holding his $\mathrm{PhD}$ and the other about to complete her $\mathrm{PhD}$ in ELT had previous experience in qualitative data analysis and were well-acquainted with the field experience system in pre-service ELT programs in Turkey. The researcher sent the coders an e-mail including the dataset, purposes of the study with a specific focus on practicum experiences and operational definitions of practicum, mentoring and RPM. The coders independently analyzed the data through the constant comparison method. They read through the dataset for the initial coding. Then, they had an individual telephone or virtual conference with the researcher, where they discussed the communication units and tentative codes they had determined as well as possible struggles they encountered in determining them. Following the conferences, the coders continued with focused coding with full freedom to modify the communication units or tentative codes whenever they perceived it necessary. Next, the researcher collected the codes and categories determined by the coders. To measure the intercoder agreement, the present study used the following formula Miles and Huberman (1994, p.64) suggested. Intercoder agreement for the content analysis surfaced to be $83 \%$, which was moderately high for a reliable intercoder agreement (Saldana, 2009).

Number of agreements

total number of agreements + disagreements

In addition, the researcher held a group meeting so as to achieve robust consensus through resolving disagreements between the coders (Harry, Sturges \& Klingner, 2005). The group meeting included the discussions and clarification of communication units/codes/categories which proved to be challenging for the coders, determination of the excerpts to be included in the report and conclusive decision on the codes and categories to be used for the representation of the data. In the meeting, the coders together with the researcher compromised to employ five categories, which featured to stand for all the components of practicum as experienced by the RPM and TM groups in an embedded fashion. Finally, the present study employed member checking in order to ensure true conformity with the data submitted by the participants. 


\section{Results}

The present study examined pre-service ELT teachers' perceptions about the overall practicum process in the light of the differential mentoring trajectories they followed throughout practicum. It employed a holistic approach to present the participants' perceptions because there were major overlaps between the RPM and TM groups. However, one should notice that the present study also made specific references to the differences between the perceptions of each group. Figure 1 briefly summarizes the participants' perceptions on overall practicum process.

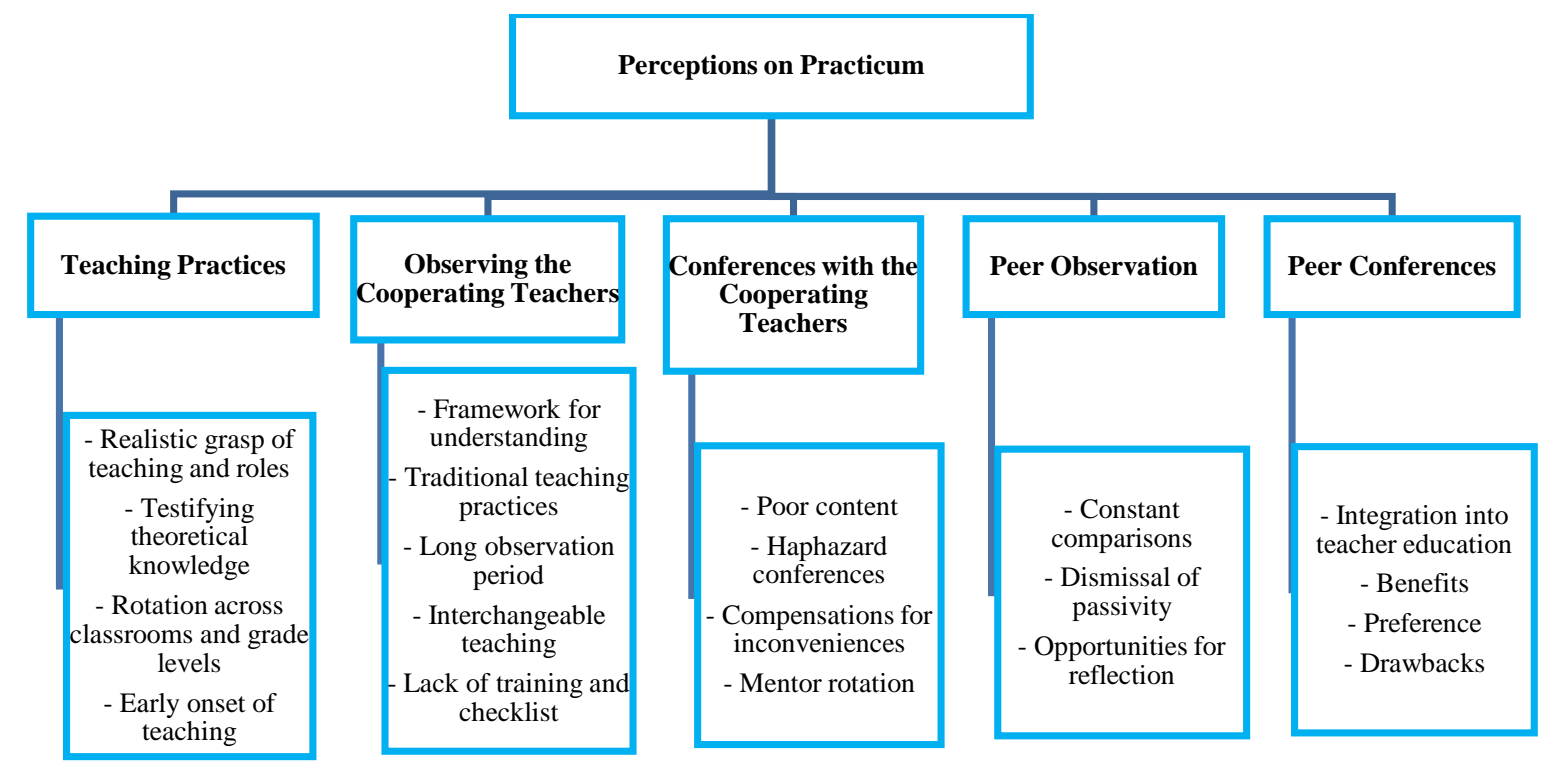

Figure 1. Perceptions on overall practicum process

\subsection{Teaching Practices}

The present study showed that as the first component of the RPM and TM models, teaching practices obviously formed a sound point of reference for the participants' development throughout the practicum process. Even though the participants in the RPM group experienced a longer period of teaching, the participants in both groups unanimously stated that teaching practices provided them with the opportunity to get a realistic grasp of teaching and the role of teacher in the classroom. The participants asserted that teaching practices gave hands-on experiences about seeing student behaviors through multi-perspectives and handling possible problems in the classroom (See Excerpt 1). In addition, the participants stated that teaching practices in practicum enabled them to testify the theoretical knowledge they had learned at the university. The participants proposed that although they had mastered the theory about teaching, teaching practices in practicum offered the first systematic opportunity to integrate their knowledge into practice and see weaknesses/strengths of various instructional strategies and techniques.

"Teaching in real classroom was useful as it gave me some ideas about multi-dimensions of student behaviors and what I might encounter in the future. Though I did not experience extreme events, I witnessed several inconveniences which I had never imagined before, and learned what I should do in those cases" (Excerpt 1- RPM-P10)

As a major shortcoming of practicum pertaining to teaching practices, the present study showed that the participants in both groups compromised on the need for a systematic rotation in practicum (See Excerpt 2). More specifically, the participants argued for periodically changing the classroom with the assumption that teaching in different classrooms would enable them to see different student profiles and construct a more comprehensive conception of teaching. Another noticeable finding about their call for 
rotation was that the participants essentially mentioned a rotation across grade levels. Put it simply, they asserted that teaching across grade levels would certainly make the rotation more fruitful as this would give them more reliable insights about teaching students at different grade levels.

"I can see whether an activity that works with young learners will work in elementary school or not, or whether controlling the young learners is easier than adolescents. Thus, it [teaching in different classes] can help me be more flexible in the classrooms... Maybe, it would have been much useful if I had taught at a primary school for five weeks and an elementary school for the other five weeks". (Excerpt 2- TM-P7)

In terms of the participants' perceptions about the amount of the teaching practices they had during practicum, the present study identified sound favor for an early onset (See Excerpt 3). The participants, particularly those in the TM group argued that confining actual teaching practices to the second term of the practicum process was a strong limitation on their development, since they perceived a period of ten weeks allocated for teaching as insufficient to develop a functional conception of teaching. Likewise, the participants in the RPM group who did spend a shorter time on observing the cooperating teachers and start practice-teaching in the first term viewed an early start with teaching as vital for further progress in practicum.

"It was definitely advantageous for us to start teaching in the first term. I have friends who did not do any teaching in the first term. When they started teaching in the second term, they could not overcome their anxiety about it and were in no way comfortable with teaching for the first 2-3 weeks... As they spent the first few weeks with this anxiety, there was not much left for them. But it was just the opposite in our case. We taught for almost a full academic year. Thus, I believe we made much more progress". (Excerpt 3- RPM-P1)

\subsection{Observing the Cooperating Teachers}

The present study unearthed that observing the cooperating teachers was a controversial component of the practicum trajectories undertaken by the RPM and TM groups. Despite the difference in the amount of time they observed the cooperating teachers (i.e. 4 versus 10 weeks of observation in the RPM and TM groups, respectively), the participants in both groups shared similar opinions about their experiences with these observations. On the one hand, they showed considerable favor for observing the practices of an experienced teacher as this would draw a broad framework for understanding various dynamics of real classrooms including "how to handle problematic students, how to teach a subject, what I should do in the classroom and how the relationship between the students and teacher should be" (TM-P4). On the other hand, they expressed dissatisfaction with observing the cooperating teachers because they perceived the teachers' practices to be too traditional and thus, fall short of meeting their needs for observing effective practices (See Excerpt 4).

"Observing the teacher was informative of course because she was an experienced teacher. But the problem was that she wanted to impose on me all her methods. She thought they were correct in terms of teaching. But I think some of them were classical like using too many repetition drills and translating the sentences into Turkish. These are not the ideal way of teaching effectively." (Excerpt 4- RPM-P7)

However, the present study found that apart from the perceptions common to both groups, the TM group reported two further criticisms about observing the cooperating teachers. First and foremost, the participants in the TM group argued that sparing the whole first term to observing the cooperating teachers was a needlessly long period. In particular, they claimed that following the first few weeks of observation, observing the teachers felt too repetitive and boring for them because there was almost nothing new in his/her teaching practices, which in turn made no further contribution to the participants' development. Alternatively, the participants in the TM group suggested that instead of spending the 
whole term by passively observing the teachers, they could have started teaching in the first term (See Excerpt 5). Yet they cautioned that they should start teaching interchangeably with the cooperating teachers and gradually increase the amount of time for teaching until they felt ready to take charge of teaching a full lesson.

"Actually, I could have started teaching from the very beginning. I mean I could have asked the teacher to change roles in a way that she would teach one week and I would teach the other week. Or she would teach one lesson and I would teach the other. In this way, it could have been better because I might not have felt ready to teach all the lessons at the beginning”. (Excerpt 5- TM-P9)

The other criticism that the participants in the TM group made about observing the teachers related to a lack of training on how to make effective observations (See Excerpt 6). Moreover, they hypothesized that having an observation checklist would make the observations more meaningful because making an overall observation of the teachers' practices seemed to be too comprehensive a task to perform. Although the teacher education program they were enrolled in provided a practicum pack involving a generic observation checklist, the participants in the TM group asked for a more specific checklist tailored to their practicum context.

"I thought that I could not observe the teacher's teaching style critically and carefully enough. I mean I was required to make observation but I did not know what effective observation was. Perhaps it would have been much better if I had received some training on what I should pay attention to while making observations". (Excerpt 6- TM-P3)

\subsection{Conferences with the Cooperating Teachers}

In the present study, the conferences with the cooperating teachers surfaced as the other controversial factor which could not fulfill the participants' expectations. Obviously, the participants in both groups attached pivotal importance to elicit the ideas and suggestions of an experienced teacher. Yet they explicitly expressed discontent about the role that the conferences played in their development. Concerning the argument about the content of the conferences, the participants in both groups proposed that the cooperating teachers did not make in-depth analyses of their performance. In particular, the participants' initial enthusiasm about the conferences seemed to fade away for such reasons as insufficient or traditional suggestions and teachers' attempts to mold pre-service teachers into their own styles of teaching. Additionally, the participants in both groups criticized the conferences with the cooperating teachers because they did not have the conferences on a systematic basis. Rather, they argued that the conferences with the cooperating teachers were haphazard and thus, failed to make the contribution that these conferences were assumed to make to pre-service teachers' development. The participants' reflections implied that busy schedule and heavy workload of the cooperating teachers were the major factors underlying the failure to schedule regular conferences (See Excerpt 7).

"If she made regular conferences with me, these would be beneficial for me. Indeed, I would learn the underlying reason of what she did while teaching, such as why she used those teaching techniques but not others. Also, I would learn about the ineffective aspects of my own practices. But she did not give detailed information because she was usually busy. She talked to me only in the breaks, which was very short." (Excerpt 7- TM-8)

Nevertheless, the present study showed that the participants in the RPM and TM groups differed in how they attempted to compensate for the inconveniences caused by the perceived inefficiency of the conferences with the cooperating teachers. On the one hand, the participants in the RPM group implied that the conferences with their peers gained more importance as they could not get sufficient guidance from the cooperating teachers. On the other hand, the participants in the TM group argued for more frequent conferences with the supervisor in order to make up for possible inconveniences (See Excerpt 
8). Interestingly though, the present study underlined that the participants in the TM group called for more conferences with the supervisor not because the supervisor would be more accessible or they would feel more comfortable with the supervisor. Instead, they reasoned that the supervisor would hold a more up-to-date knowledge of teaching methodologies and prove a better resource to fall back on for feedback about their performance and suggestions to resolve their struggles in practicum.

"... she [the cooperating teacher] was a bit more traditional. That's why she was of little help to see our mistakes or deficiencies. Or she viewed some old-fashioned practices as appropriate, which were inappropriate according to the modern teaching approaches. But I think if we had the opportunity to meet the supervisor more frequently, it would be more useful because he could inform us about our mistakes more precisely". (Excerpt 8- TM-P9)

Furthermore, the present study showed that another point distinguishing the RPM and TM groups in terms of their perceptions of the conferences with the cooperating teachers was the RPM group's call for mentor rotation (See Excerpt 9). That's the participants in the RPM group argued for periodically changing the cooperating teachers with whom they worked throughout practicum. They pointed out that changing the cooperating teachers at certain intervals would maximize the benefit they could make from practicum on the grounds that each teacher had different styles and working with more than one teacher during practicum could help them establish a more comprehensive conception of effective teaching.

"Teachers have their own unique teaching styles and perspectives... What one teacher offers me will be different from what another teacher offers. If we had changed the teachers on a regular basis, it would have been like producing honey from different flowers." (Excerpt 9- RPM-P10)

\subsection{Peer Observation}

One of the components specific to the practicum trajectory pursued by the RPM group, peer observation emerged to be a salient factor contributing to the pre-service teachers' development throughout the practicum process. The present study unearthed that peer observations served a major function to help the RPM group see not only the peer's strengths and weaknesses but also their own strengths and weaknesses because they were constantly making comparisons between the peer's and their own teaching practices. In addition, the present study highlighted that the most distinctive contribution of peer observations was the dismissal of perceived passivity associated with making observation. Knowing that the observations they made in their peer's classroom would form the basis of the reflections they would make in the post-teaching conferences urged the participants to critically observe their peer and actively note down the strengths and weaknesses in his/her performance. Hence, one may postulate that this knowledge further contributed to the success of peer observations in activating pre-service teachers because it made them take on the responsibility of one another's development to some extent. The present study also found that peer observations provided the participants in the RPM group with salient opportunities to think reflectively and devise alternative solutions for possible problems (See Excerpt 10).

"I and my peer were thinking multi-dimensions of our activities. As we observed each other's practices, we were constantly searching for a,b,c plans for the problems in our practices. Observing what caused the problem in my peer's practice, I was thinking that it did not work this way and I should try it out in that way or I should make some modifications before I used it in my own teaching". (Excerpt 10- RPM-P7)

\subsection{Peer Conference}

As the other component of the RPM trajectory, peer conference featured to be another critical factor that affected the participants' overall development throughout the practicum process. The present study 
provided sound evidence about the argument that peer mentoring practices should be an integral part of teacher education programs because the discussions the peers held during pre- and post-teaching conferences surfaced to make invaluable contributions to their professional development. An in-depth analysis of the RPM groups' perceptions about peer conferences revealed that peer conferences provided pre-service teachers with considerable assistance to handle the problems they encountered during the practicum experiences. Therefore, the present study confirmed that particularly in the paucity of support from the cooperating teachers or supervisor, peer conferences could serve as an invaluable resource feeding into pre-service teachers' development.

More specifically, the present study indicated that holding systematic peer conferences offered several benefits. To start with, peer conferences provided the participants with considerable social, psychological and professional support throughout the practicum process. The present study also revealed that a significant contribution of peer conferences pinpointed the role of peer conferences in increasing pre-service teachers' awareness about their practices. The participants in the RPM group emphasized that the discussions with the peers enabled them to get a more precise understanding of their own teaching performance because these discussions essentially included in-depth reflections on their teaching practices and thus, helped them realize things they missed while teaching in the classroom. In the same vein, the present study conveyed that peer conferences were beneficial for improving the participants' pedagogical content knowledge. The participants asserted that while exchanging opinions about how to teach effectively during peer conferences, they needed to refer to their methodological knowledge in order to justify their opinions. In so doing, they resorted to the internet, the notes they had taken in the methodology courses and the books they had read in those courses, which in turn polished their knowledge of L2 teaching methodology (See Excerpt 11). Consequently, the present study contradicted the criticism that as pre-service teachers, the peer pairs were relatively inexperienced in teaching and thus might not provide sufficient assistance to one another.

"I had to review my theoretical knowledge about different issues. I mean we had learned a lot of strategies in the methodology courses but honestly, I had forgotten some of them. But the conferences made me remember them in a short time because I felt obliged to frequently repeat them." (Excerpt 11RPM-P1)

An interesting finding about peer conferences was a noticeable preference the RPM group expressed for the conferences they had with their peers over those conferences with the cooperating teachers. The present study showed that among others, six major reasons underlying the participants' preference for peer conferences included a) the consistency in holding the conferences, b) the opportunity to set their own goals for the conferences, c) holding conferences with a peer who knew everything about their lesson, d) friendly atmosphere of peer conferences, e) the reciprocity in the very nature of peer conferences and f) the opportunity to select the peers with whom they would work throughout practicum (See Figure 2). 


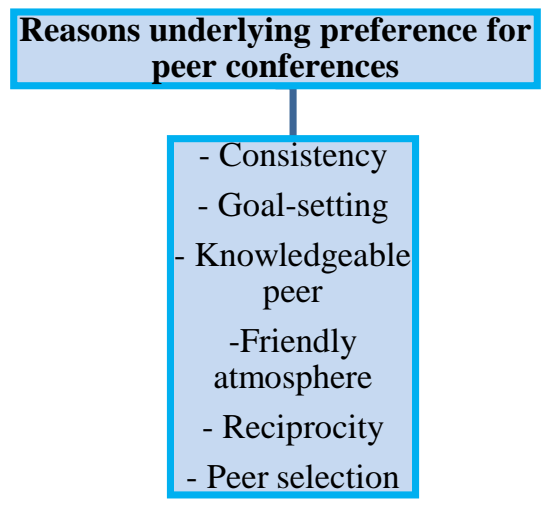

Figure 2. Reasons underlying the RPM group's preference for peer conferences

Nonetheless, the present study found two major drawbacks associated with peer conferences. Firstly, the present study unearthed that a possible limitation on peer conferences might simply be scheduling the conferences at mutually appropriate times, especially when the peers had additional responsibilities. Secondly, the present study illustrated that the support peer conferences supplied about classroom management was not satisfactory at times. More precisely, peer conferences might fall short of generating alternative suggestions that would solve pre-service teachers' classroom management problems encountered during the practicum experiences. Yet one should notice that all the cases where the RPM group perceived peer conferences to be insufficient pertained to their assumed possibility of encountering extreme discipline problems, about which a peer with similar inexperience would probably be of little or no help (See Excerpt 12). More interestingly, the present study pointed out that some of the participants expressing skepticism about efficiency of peer conferences in handling possible extreme problems intriguingly admitted that even the experienced cooperating teachers would not be of much help in such incidents. Henceforth, the present study ascertained that the participants' dissatisfaction with peer conferences in providing support for classroom management should be tentatively handled because their dissatisfaction might have stemmed from a probable misconception of the participants about solving classroom management issues. Given their reflections about the role of peer conferences in classroom management, the participants in the RPM group might have expected to get a conclusive and all-encompassing prescription that would free them from all classroom management issues at once.

"We both did not know how we should react in case of an extraordinary problem about management. We would be confused in such a case. It would have been better if there had been somebody with more experience. Indeed, I needed a more experienced person in terms of classroom management because an experienced person would have encountered such problems perhaps a hundred times". (Excerpt 12RPM-P5)

\section{Discussion}

Examining pre-service ELT teachers' perceptions of the overall practicum process, the present study reinforced the assertion that practicum was one of the critical components of effective teacher education (Smith \& Lev-Ari, 2005). The pre-service teachers in both groups unanimously stated that they gained practical insights about themselves as teachers, their role in actual classroom environments and how to manage various dynamics of such environments to produce positive learning outcomes not only for their 
students but for themselves. In particular, the present study highlighted that specific experiences offered in practicum (RPM and TM practices in the case of the present study) played differential roles in realizing perceived contributions that taking practicum might make to pre-service teachers' personal and professional development. Therefore, the present study underlined that engaging pre-service teachers in as varied experiences as possible during practicum could be conducive for growing effective practitioners who could collaborate to critically reflect on their performances, identify and address weaknesses in their teaching practices and volunteer for further work to improve their teaching effectiveness.

With respect to the various components of practicum as perceived by the participants, the present study unearthed that teaching practices constituted a bedrock for pre-service teachers' development throughout practicum. The hands-on experiences the RPM and TM groups had during practicum enabled them to get a realistic grasp of teaching and their role as a teacher in the classroom. This finding echoed previous studies which showed that hands-on teaching practices improved pre-service teachers' confidence (Ulvik \& Smith, 2011) and enhanced the development of their own teaching style (Haigh, Pinder \& McDonald, 2006). As part of the positive attitude towards teaching practices, the present study revealed that teaching practices in practicum were a significant resource for pre-service teachers to testify their theoretical knowledge. This finding contributed to the recent calls for more hands-on experiences in teacher education programs in order to foster pre-service teachers' integration of university education into classroom settings (Dreyer, 1998).

Besides, the present study intriguingly pinpointed a need for systematic rotations in practicum. The study placed a premium on periodically changing the classroom and grade levels in which pre-service teachers taught so that they could gain in-depth awareness about various student profiles and make more informed decisions in their teaching. Previous research (Goodwyn, 1997; Foster, 1999) yielded similar reflections about enabling rotations during practicum. Comparing the initial practicum placements of pre-service teachers in the UK and France, Foster (1999) postulated that wider opportunities to teach different age groups and different classrooms would make more profound contributions to pre-service teachers' professional development. Moreover, the present study clarified that the earlier pre-service teachers started practice-teaching, the better it would be for their professional development. Many other studies (Campbell-Evans \& Maloney, 1997; Hudson \& Nguyen, 2008) reported that extending the observation period at the expense of teaching practices would put strong limitations on the effectiveness of practicum. Instead, earlier and more opportunities for teaching practices could profoundly supplement pre-service teachers' understanding of their role as a teacher as well as the strengths and weaknesses in their teaching practices.

With regard to observing the cooperating teachers, the present study revealed controversial findings about how pre-service teachers perceived the observation experiences during practicum. The study clarified that different amount of time spent on observing the cooperating teachers notwithstanding, the participants in both groups expressed favor for observing the practices of experienced teachers as this would give insights about how to carry out their own teaching practices and manage various dynamics of the classroom successfully. Anderson, Barksdale and Hite (2005) confirmed this finding as they emphasized that observing the cooperating teachers positively influenced pre-service teachers' practices through enabling them to develop and integrate effective teaching practices modeled by the cooperating teachers. Yet the present study indicated that the initial favor for observing the cooperating teacher seemed to fade away due to the participants' perception that the cooperating teachers mostly operated with too traditional practices, which in turn gave rise to overall dissatisfaction with the observations. Based on this finding, the present study underscored the role of selecting and recruiting appropriate cooperating teachers who could provide models of good professional practice. 
Similarly, the present study challenged the current practicum system in which observation and teaching practices formed two discrete units and pre-service teachers spent the first half of practicum on observing the cooperating teachers while they got engaged in actual teaching only in the second half. The study clearly criticized that passively observing the cooperating teachers for a whole semester without any hands-on teaching experience was impractical because it deprived pre-service teachers of opportunities to gain more practical experiences. Consonant with the participants' argument for interchangeable teaching, Foster (1999) recommended that the cooperating teachers serve as a fellow enquirer and encourage pre-service teachers to develop their own teaching styles through reflectively questioning conventional norms and practices. As a result, the present study suggested a gradual transition model, in which pre-service teachers together with the cooperating teachers began teaching as early as possible and gradually took on more responsibilities until they felt ready for individually taking charge of a full lesson. The other criticism the present study conveyed about observing the cooperating teachers in practicum pointed to a lack of training on what to observe and how to observe effectively. Paying heed to Anderson et al.'s (2005) suggestions, the present study presumed that along with providing training on effective observation techniques, involving pre-service teachers in a combination of guided and unguided observations may be a viable alternative to promote their gains from the observations. Besides, providing observation tools which would broadly reflect the goals of observation and overall practicum might help to make the observations more meaningful for pre-service teachers (Jenkins, Garn \& Jenkins, 2005).

Considering the conferences with the cooperating teachers, the present study revealed that despite the optimism about their contributions, the conferences with the cooperating teachers provided the participants with only limited guidance basically due to two reasons, which featured more like criticisms about the conferences. On the one hand, the conferences were poor in content with superficial analysis of the pre-service teachers' performance and taken-for-granted suggestions for improvement. As evidenced in the literature (Hardy, 1999; McNamara, 1995), this lack of professional guidance was obviously far from responding to the participants' unanimous call for reflective feedback from the cooperating teachers to develop a deeper understanding of effective teaching. On the other hand, the conferences appeared to be rather infrequent and haphazard now that the cooperating teachers hardly availed themselves for the conferences with the pre-service teachers. In line with previous studies (Beck \& Kosnick, 2000; Boreen, Johnson, Niday \& Potts, 2009), this finding pointed to the necessity for scheduling regular conferences. Overall, one might associate this lack of satisfactory guidance by the cooperating teachers with the largely neglected issue of mentor training. As the current mentoring system in Turkey did not necessarily involve the cooperating teachers in training about effective mentoring, the cooperating teachers in the present study might not have been aware of the goals and principles of how best to collaborate with pre-service teachers to foster their professional development during practicum. That's why the present study just like numerous other studies (Foster, 1999; ÖrsdemirPanpall1, 2016) recommended that teacher education programs provide mentor training which would ably inform the cooperating teachers of the techniques and strategies to effectively help pre-service teachers develop their professional identity.

Interestingly though, the present study yielded alternative choices that the pre-service teachers suggested to partly compensate for the inconveniences associated with the conferences with the cooperating teachers. The study unearthed that for the participants in the RPM group, peer conferences constituted a supplementary mechanism strong enough to provide satisfactory guidance for solving their problems. The RPM groups' emphasis on peer support verified McCarthy and Youens' (2005) qualitative study, in which pre-service teachers preferred peer support as they perceived the cooperating teachers and university supervisor as an infrequent and less useful source of support. The participants in the TM group, however, unanimously required more opportunities to meet the university supervisor. 
A possible explanation for the TM group's argument for more conferences with the university supervisor might be that in contrast to the well-established role of the cooperating teachers as a critical contributor to pre-service teachers' development (Borko \& Mayfield, 1995), the participants in the present study might have assigned more credibility to the university supervisor than the cooperating teachers. As the other alternative to compensate for possible inconveniences associated with the conferences with the cooperating teachers, the present study openly called for mentor rotation in practicum. As there can be no ideal mentor who can provide all the guidance and assistance that each and every pre-service teacher needs, the opportunity to change the cooperating teachers without giving offence to either end of the mentoring relationship can at times be a must, particularly in cases where the relationship seems unproductive (Association for Supervision and Curriculum Development, 1999).

With particular reference to the perceptions about peer observation as one of the two components specific to the RPM trajectory, the present study placed a premium on the comparisons the observing peers made between their own teaching and that of the observed. Consistent with findings of several studies (Forbes, 2004; Joyce \& Showers, 1995), the pre-service teachers in this study seemed to keep their own practices at the forefront of their minds during peer observation because they frequently compared what they observed in their peers' teaching to their own practices and tried to learn from the peers' struggles and achievements in teaching. The prevalence of comparisons accorded with the argument that peer observations provided pre-service teachers with valuable time and space for making in-depth analyses of what they observed and how they could improve their own teaching on the basis of these analyses (Jenkins et al. 2005; Jenkins \& Veal, 2002). The most prominent contribution of peer observations, as the present study revealed, was the elimination of the perceived passivity of pre-service teachers while making observations in practicum. The active role pre-service teachers undertook through critically observing and taking notes during peer observations represented perfect match with Le Cornu's (2008) conception of recently shifting roles of pre-service teachers as "pro-active learners, empathic and skilled communicators, emotionally strong and resilient" (p. 12). Based on these findings, the present study verified that peer observation formed a major opportunity for learning about teaching in that it prompted valuable insights into different instructional strategies and new ideas to improve teaching effectiveness (Neubert \& Stover, 1994). Given that teachers might not always have the opportunity to do observation in the professional life despite perceived benefits in it (Zwart et al., 2009), the present study asserted that it would be promising to engage pre-service teachers in peer observation so as to provide them with an effective means of handling complexities of learning to teach in practicum.

As for the other component specific to the RPM trajectory, the present study confirmed McCarthy and Youens' (2005) finding that as an underused resource, peer conferences provided worthwhile social, psychological and professional support well-tailored to pre-service teachers' specific context of teaching. Given the notorious conception of practicum as a lonely struggle characterized with lack of support (Neubert \& Stover, 1994), peer conferences also surfaced to be instrumental in reducing preservice teachers' loneliness during the painstaking endeavor of learning to teach. Moreover, the present study elucidated that peer conferences were inherently rewarding as they enabled pre-service teachers to develop a more thorough understanding of their performance on the basis of reflections exchanged during these conferences. Hornberger, Askvig and Arrayan (2002) in part justified this finding as they advocated that peer conferences facilitated the development of an in-depth analysis of teaching because discussions in peer conferences encouraged critical reflections on not only strengths but also weaknesses. Similarly, the present study ascertained that peer conferences had a profound impact on the participants' development of pedagogical content knowledge. Echoing the findings of a large number of studies (Hasbrouck, 1997; Jenkins et al., 2005), the present study unearthed considerable gains in preservice teachers' knowledge about instructional strategies, techniques and approaches as a result of engagement in peer conferences. In the same vein, the present study identified noticeable preference for 
holding conferences with someone of equal knowledge and experience. A large number of studies validated this finding by reporting high pre-service teacher satisfaction with peer conferences (Zwart et al., 2008) and a desire to continue to use it in their professional career (Britton \& Anderson, 2010).

Nevertheless, the present study conveyed that peer conferences were not risk-free as they presented some drawbacks requiring specific consideration. One of the two major drawbacks associated with peer conferences related to finding mutually appropriate time for the conferences, which apparently several studies (Forbes, 2004; Kurtts \& Levin, 2000) documented as a barrier to effective functioning of the RPM practices. Luckily though, the present study unraveled some insider suggestions that could possibly help to overcome the issue about time commitment for peer conferences. Firstly, pre-service teachers arranged to engage in RPM during practicum should enjoy the opportunity to select their peer who should preferably be compatible in terms of coursework schedule and proximity (Britton \& Anderson, 2010). Also, they might negotiate with the cooperating teachers and university supervisor about flexibility in the practicum program because this would facilitate their endeavor to find mutually appropriate time for peer conferences (Lu, 2010). The present study further premised that pre-service teachers should have the freedom to hold virtual conferences apart from face-to-face conferences (Le Cornu, 2005). Considering the demanding nature of all briefing, observation and debriefing activities embedded in the RPM practices (Foster, 1999), another viable suggestion to ease the time constraints of peer conferences might be to reduce pre-service teachers' workload in other courses that run concurrent with the practicum period.

The other drawback, as the present study revealed, was the perceived inadequacy of peer support, particularly for classroom management. The participants' dissatisfaction with peer conferences due to inadequate support about classroom management was undoubtedly no surprise given that several studies (Forbes, 2004; Jenkins \& Veal, 2002) identified classroom management as the pre-dominant concern not only for pre-service but also novice and even experienced teachers. Nonetheless, the present study cautioned that although it was still a salient finding, the participants' dissatisfaction with peer conferences required tentative elaboration because the participants partaking in peer conferences reported no actual instance of extreme management problems, for which they assumed the peers' support would not suffice to suggest a practical solution. The present study speculated that a possible reason underlying the participants' dissatisfaction with peer conferences might be that being new to the RPM practices as well as actual teaching practices, the participants might have recognized a need for an authority to make the ultimate comment and thus, reported dissatisfaction with peer conferences. Various studies (Forbes, 2004; Henning, Weidner \& Jones, 2006) confirmed this stance as they conveyed that despite harboring relatively positive attitudes towards working with peers, teachers perceived additional value to get affirmation from a more experienced peer.

\section{Conclusions}

To sum up, the present study evinced that integration of the RPM model could form a viable enhancement to resolve the abovementioned drawbacks of the TM practices. In particular, the present study premised that an earlier onset of teaching practices through periodic rotations across classrooms and grade levels could give pre-service teachers a more comprehensive conception of teaching. Similarly, peer observations spread over the whole practicum period emphasized improvement over evaluation and notably contributed to the elimination of perceived passivity of pre-service teachers during observations. Furthermore, systematic peer conferences as the bedrock of the RPM protocols proved to be a prominent resource feeding into pre-service teachers' professional development. The present study elucidated that apart from the substantial social, psychological and professional support, 
the reflective dialogues embedded in the very nature of peer conferences enhanced pre-service teachers' overall development in practicum. Henceforth, the present study concluded that the RPM model should be an integral part of the practicum process as an alternative to supplement pre-service teachers' professional identity development.

\section{References}

Anderson, N. A., Barksdale, M. A., \& Hite, C. E. (2005). Preservice teachers' observations of cooperating teachers and peers while participating in an early field experience. Teacher Education Quarterly, 32(4), 97-117.

Association for Supervision and Curriculum Development. (1999). Mentoring to improve schools. Alexandria, VA: ASDC.

Beck, C., \& Kosnick, C. (2000). Associate teachers in pre-service education: Clarifying and enhancing their role. Journal of Education for Teaching: International Research and Pedagogy, 26(3), 207224.

Boreen, J., Johnson, M. K., Niday, D., \& Potts, J. (2009). Mentoring beginning teachers: Guiding, Reflecting, Coaching. Portland: Stenhouse Publishers.

Borko, H., \& Mayfield, V. (1995). The roles of the cooperating teacher and university supervisor in learning to teach. Teaching and Teacher Education, 11(5), 501-518.

Britton, L. R., \& Anderson, K. A. (2010). Peer coaching and pre-service teachers: Examining an underutilised concept. Teaching and Teacher Education, 26, 306-314.

Campbell-Evans, G., \& Maloney, C. (1997). An alternative practicum curriculum: Exploring roles and relationships. Asia-Pacific Journal of Teacher Education, 25(1), 35-52.

Creswell, J. W. (2012). Educational research: Planning, conducting and evaluating quantitative and qualitative research (4th ed.). Boston: Pearson.

Darling-Hammond, L. (2006). Constructing 21st-century teacher education. Journal of Teacher Education, 57(3), 300-314.

Dreyer, J. (1998). The use of mentors (experienced teachers) as school-based experts to assist student and beginning teachers. South African Journal of Education, 18, 109-112.

Forbes, C. T. (2004). Peer mentoring in the development of beginning secondary science teachers: Three case studies. Mentoring and Tutoring: Partnership in Learning, 12(2), 219-239.

Foster, R. (1999). School-based initial teacher training in England and France: Trainee teachers' perspectives compared. Mentoring and Tutoring: Partnership in Learning, 7(2), 131-143.

Goh, P. S., \& Matthews, B. (2011). Listening to the concerns of students teachers in Malaysia during teaching practice. Australian Journal of Teacher Education, 36(3), 92-102.

Goodwyn, A. (1997). Developing English teachers: The role of mentorship in a reflective profession. Buckingham: Open University Press.

Haigh, M., Pinder, H., \& McDonald, L. (2006). Practicum's contribution to students' learning to teach. Paper presented at the British Educational Research Association Annual Conference, Coventry, UK. Retrieved from http://www.leeds.ac.uk/educol/documents/160597.htm on 08.05.2017. 
Hardy, C. A. (1999). Perceptions of physical education beginning teachers' first year of teaching: Are we doing enough to prevent early attrition?. Teacher Development, 3(1), 109-127.

Hargraves, D. H. (2001). A capital theory school effectiveness and improvement. British Educational Research Journal, 27(4), 487-503.

Harry, B., Sturges, K. M., \& Klingner, J. K. (2005). Mapping the process: An exemplar of process and challenge in grounded theory analysis. Educational Researcher, 34(2), 3-13.

Hasbrouck, J. E. (1997). Mediated peer coaching for training preservice teachers. The Journal of Special Education, 31(2), 251-271.

Henning, J. M., Weidner, T. G., \& Jones, J. (2006). Peer-assisted learning in athletic training clinical setting. Athletic Training Education Journal, 41(1), 10-108.

Hooker, T. (2014). The benefits of peer coaching as a support system for early childhood education students. International Journal of Evidence Based Coaching and Mentoring, 12(1), 109-122.

Hornberger, B., Askvig, B., \& Arrayan, K. (2002). Follow-up of online instruction: Effectiveness of peer coaching seminar course. Prism project technical report. (Report No. PRISM-3). North Dakota Center for Persons with Disabilities, Minot. (ERIC Document Reproduction Service No. 475859).

Hudson, P., \& Nguyen, T. M. H. (2008). What do preservice EFL teachers expect from their mentors?. In Proceedings of AARE Conference: Changing Climates: Education for Sustainable Futures. Retrieved from http://www.aare.edu.au/data/publications/2008/hud08144.pdf on 09.05.2017.Joyce, B. \& Showers, B. (1980). Improving inservice training: The messages of research. Educational Leadership, 37(5), 379-385.

Jenkins, J. M., Garn, A., \& Jenkins, P. (2005). Preservice teacher observations in peer coaching. Journal of Teaching in Physical Education, 24, 2-23.

Jenkins, J. M., \& Veal, M. L. (2002). Preservice teachers' PCK development during peer coaching. Journal do Teaching in Physical Education, 22, 49-68.

Joyce, B. R., \& Showers, B. (1995). Student achievement through staff development: Fundamentals of school renewal (2nd ed.). White Plains, NY: Longman.

Kurtts, S. A., \& Levin, B. B. (2000). Using peer coaching with preservice teachers to develop reflective practice and collegial support. Teaching Education, 11(3), 297-310.

Kuru-Gönen, S. I. (2013). A study on reflective reciprocal peer coaching: An application in preservice English language teaching context. Unpublished doctoral dissertation: Anadolu University, Eskişehir.

Le Cornu, R. (2005). Peer mentoring: Engaging pre-service teachers in mentoring one another. Mentoring \& Tutoring: Partnership in Learning, 13(3), 355-366.

Le Cornu, R. (2008). The changing role of the 'student teacher' in professional experience. Paper presented at the Australian Association for Research in Education Conference, Brisbane.

Levine, M. (2002). Why invest in professional development schools?. Educational Leadership, 6, 6568.

Lu, H. L. (2010). Research on peer coaching in preservice teacher education: A review of literature. Teaching and Teacher Education, 26, 748-753. 
McCarthy, S., \& Youens, B. (2005). Strategies used by science student teachers for subject knowledge development: A focus on peer support. Research in Science and Technological Education, 23(2), 149-162.

McDonald, F. J., \& Elias, P. (1983). The transition into teaching: The problems of beginning teachers and programs to solve them. Retrieved from http://files.eric.ed.gov/fulltext/ED257777.pdf on 07.28.2016.

McNamara, D. (1995). The influence of student teachers' tutors and mentors upon their classroom practice: An exploratory study. Teaching and Teacher Education, 11(1), 51-61.

Miles, M. B., \& Huberman, A. M. (1994). Qualitative data analysis: An expanded sourcebook (2nd ed.). Thousand Oaks, CA: Sage Publications.

Neubert, G. A., \& Stover, L. T. (1994). Peer Coaching in Teacher Education (Fastback 371). Bloomington: Phi Delta Kappa Educational Foundation. ERIC Doc No: ED 378140. Retrieved from http://files.eric.ed.gov/fulltext/ED378140.pdf on 05.04.2017.

Nguyen, H. T. M. (2013). Peer mentoring: A way forward for supporting preservice EFL teachers psychosocially during the practicum. Australian Journal of Teacher Education, 38(7), 31-44.

Örsdemir-Panpall1, E. (2016). Becoming a mentor: An action research on enhancing an EFL teacher's mentoring skills in Turkey. Unpublished doctoral dissertation: Çukurova University, Adana.

Paris, L. (2010). Reciprocal mentoring residencies... Better transitions to teaching. Australian Journal of Teacher Education, 35(3), 14-26.

Parker, P., Douglas, T. H., \& Kram, K. E. (2008). Peer coaching: A relational process for accelerating career learning. Academy of Management Learning and Education, 7(4), 487503.

Richards, J. C., \& Ho, B. (1998). Reflective thinking through journal writing. In J. C. Richards (Ed.), Beyond Training (pp. 153-170). Cambridge: Cambridge University Press.

Saldana, J. (2009). The coding manual for qualitative researchers. Thousand Oaks, CA: Sage Publications.

Showers, B., \& Joyce, B. (1996). The evolution of peer coaching. Educational Leadership, 53(6) $12-$ 16.

Smith, K., \& Lev-Ari, L. (2005). The place of the practicum in pre-service teacher education: The voice of the students. Asia-Pacific Journal of Teacher Education, 33(3), 289-302.

Ulvik, M., \& Smith, K. (2011). What characterises a good practicum in teacher education?. Education Inquiry, 2(3), 517-536.

Vidmar, D. J. (2006). Reflective peer coaching: Crafting collaborative self-assessment in teaching. Research Strategies, 20, 135-148.

Walsh, K., Elmslie, L., \& Tayler, C. (2002) Pairs on practicum (trial): Early childhood students collaborate with peers in preschool/kindergarten. Paper presented at the Australian Association for Research in Education (AARE) Conference, Brisbane, Queensland, December 1-5, 2002.

Wynn, M., \& Kromrey, J. (2000). Paired peer placement with peer coaching to enhance prospective teachers' professional growth in early field experience. Action in Teacher Education, 22(2A), 7383. 
Zeichner, K. (2010). Rethinking the connections between campus courses and field experiences in college- and university-based teacher education. Journal of Teacher Education, 61(1-2), 89-99.

Zwart, R. C., Wubbels, T., Bergen, T., \& Bolhuis, S. (2009). Which characteristics of a reciprocal peer coaching context affect teacher learning as perceived by teachers and their students?. Journal of Teacher Education,60(3), 243-257.

Zwart, R.C., Wubbels, T., Bulhois, S., \& Bergen, T. (2008). Teacher learning through reciprocal peer coaching: An analysis of activity sequences. Teaching and Teacher Education, 24, 982-1002.

\section{Hizmet öncesi öğretmenlerin karşılıklı akran danışmanlığ ve geleneksel danışmanlık yoluyla öğretmenlik uygulaması algıları}

\section{$\ddot{O} \mathbf{z}$}

Hizmet öncesi öğretmen eğitiminde öğretmenlik uygulaması, uygulamalı bir öğretme ve öğrenme anlayış1 geliştirmek için büyük olanaklar sunar. Ancak yeterli kaynaklar sunulmadığı ve dikkatli şekilde yapılandırılmadığı zaman bu uygulama, öğretmen adaylarında daha yüksek endişeye de yol açabilir. Bu çalışma, öğretmen adaylarının karşılıklı akran danışmanlığı ve geleneksel danışmanlık yöntemleriyle tamamlanan öğretmenlik uygulamasına ilişkin görüşlerini incelemeyi amaçlamıştır. Yarı-deneysel olarak tasarlanan bu boylamsal çalışma, yansıtıcı günlükler, bireysel görüşme ve akran görüşmelerinin ses kayıtları vasıtasıyla nitel very toplamıştır. Çalışma, halihazırda hizmet öncesi eğitim programlarında kullanılan geleneksel danışmanlık modelinin yeniden yapılandırılmasına acil ihtiyaç olduğunu göstermiştir. Bu çalışma aynı zamanda sistematik akran görüşmesi ve akran gözlemi imkanlarıyla karşılıklı akran danışmalığı entegrasyonunun, öğretmenlik uygulamasında gözlemlenen eksiklikleri gidermek için uygun bir seçenek olduğunu göstermiştir. Ayrıca çalışma, öğretme uygulamalarına daha erken başlamanın yanı sıra öğretme uygulamalarında ve mentor-öğrenci eşleşmelerinde periyodik rotasyonların öğretmenlik uygulamalarının katkılarının en üst düzeye çıkarılmasına yardımcı olabileceğini ortaya koymuştur.

Anahtar sözcükler: öğretmenlik uygulaması; danışmanlık; geleneksel; akran; karşılıklı

\section{AUTHOR BIODATA}

Assit.Prof. Dr. Seyit Ahmet ÇAPAN holds a BA degree in English Language Teaching from Hacettepe University. He received his MA degree in English Language Teaching from Necmettin Erbakan University and PhD degree in English Language Teaching from Çukurova University. He worked as an ELT practitioner at secondary and tertiary levels. He is currently working at Harran University English Language Teaching Department. His research interests include language teacher education, integration of technology into language classrooms and individual differences.

Assoc. Prof. Dr. Hasan Bedir is a graduate of ELT Department Faculty of Education, Cukurova University. He completed his MA and Ph.D at the same university. He is studying on Teacher Education and 21st Century Skills. He is specifically teaching Educational Research Methods, Teaching English to Young Learners and Material Evaluation and Development at undergraduate level, Critical Thinking in ELT at MA and Current Trends in Teacher Education at Ph.D. He is currently doing research on education for sustainable development (ESD). 